\title{
Correction: High-resolution HLA phased haplotype frequencies to predict the success of unrelated donor searches and clinical outcome following hematopoietic stem cell transplantation
}

\author{
Stéphane Buhler · Helen Baldomero - Sylvie Ferrari-Lacraz • José Manuel Nunes - Alicia Sanchez-Mazas • \\ Stravroula Massouridi-Levrat • Dominik Heim • Jörg Halter · Gayathri Nair • Yves Chalandon • Urs Schanz • \\ Tayfun Güngör · Grazia Nicoloso (1) · Jean-Marie Tiercy · Jakob Passweg · Jean Villard
}

Published online: 4 May 2020

(c) The Author(s) 2020. This article is published with open access

Correction to: Bone Marrow Transplantation (2019) 54: $1701-1709$

https://doi.org/10.1038/s41409-019-0520-6

published online 05 April 2019

This Article was originally published under Nature Research's License to Publish, but has now been made available under a [CC BY 4.0] license. The PDF and HTML versions of the Article have been modified accordingly.
Open Access This article is licensed under a Creative Commons Attribution 4.0 International License, which permits use, sharing, adaptation, distribution and reproduction in any medium or format, as long as you give appropriate credit to the original author(s) and the source, provide a link to the Creative Commons license, and indicate if changes were made. The images or other third party material in this article are included in the article's Creative Commons license, unless indicated otherwise in a credit line to the material. If material is not included in the article's Creative Commons license and your intended use is not permitted by statutory regulation or exceeds the permitted use, you will need to obtain permission directly from the copyright holder. To view a copy of this license, visit http://creativecommons. org/licenses/by/4.0/. 